\title{
Znáte plat svého šéfa? V Mondragonu vědí nejen to...
}

\section{Beáta Binková}

\author{
Envigogika 9 (2) - Inspirace/ Inspiration
}

Publikováno/Published 30. 11. 2014

DOI: $10.14712 / 18023061.464$

\begin{abstract}
Abstrakt
Rada vlády pro udržitelný rozvoj uspořádala dne 14. října 2014 v budově Úřadu vlády seminář "Jak podpořit podnikání v ČR pomocí finanční spoluúčasti zaměstnanců? inspirace jménem Mondragon", jehož cílem bylo v návaznosti na trendy EU identifikovat překážky a zajistit praktické kroky $\mathrm{k}$ odstranění bariér vedoucích $\mathrm{k}$ finanční spoluúčasti zaměstnanců $v$ ČR. Semináře se zúčastnili zástupci Mondragonské družstevní korporace, která již 58 let prosazuje finanční spoluúčast zaměstnanců. Ta je důležitým ekonomickým nástrojem, který $v$ České republice není př́liš využíván. $Z$ tohoto důvodu také Vladimír Špidla, člen Rady vlády pro udržitelný rozvoj a ředitel Odboru poradců a poradkyň premiéra Bohuslava Sobotky, vyjádřil vážný zájem o podporu zaměstnanecké spoluúčasti, oživení družstevnictví a využití jeho potenciálu v České republice.
\end{abstract}

\section{Klíčová slova:}

Udržitelný rozvoj; Rada vlády pro udržitelný rozvoj; Mondragonská družstevní korporace; finanční spoluúčast zaměstnanců

\begin{abstract}
The Government Council for Sustainable Development organized a seminar called "How to promote business in the country through the financial participation of employees? - Inspiration behalf of Mondragon" at the Government Office Building on 14 October 2014. The seminar focused on EU trends to identify barriers and ensure practical steps to remove barriers leading to financial contributions of employees in the country. The seminar was attended by representatives of the Mondragon Cooperative Corporation, which has been promoting employee financial participation for the last 58 years. This is an important economic tool that is not greatly used in the Czech Republic. For this reason, Vladimír Špidla, a member of the Government Council for Sustainable Development and Director of the Department of Advisors to Prime Minister Bohuslav Sobotka, expressed serious interest in the promotion of employee financial contributions, the revival of cooperatives and the utilization of their potential in the Czech Republic.
\end{abstract}

\section{Key words}

Sustainable development; Government Council for Sustainable Development; Mondragon Cooperative Corporation, employee financial contributions 


\section{Úvod}

Náš ekonomický systém se ještě plně nezotavil z finanční krize, která po americké hypoteční krizi z roku 2007 postihla dominovým efektem celý svět. Očekává se kolaps virtuální ekonomiky (záleží, za jak dlouhou dobu se masový únik milionů lidí z reality do kyberprostoru odrazí v širším společenském kontextu), narưstají obavy z tzv. "kasínového kapitalismu" (Strange, 1986), kdy je sociální stát likvidován těmi nejbohatšími a stává se institucí chránící kumulaci soukromého zisku. O ekonomickém „bytí či nebytí rozhoduje finanční kapitál, který má však čím dál víc omezené investice, vzhledem k tomu, že zadlužené obyvatelstvo se stagnujícími př́ijmy bojuje se splátkami a úroky. A tak je žeton kapitálových rezerv vržen do viŕící rulety spekulativního byznysu a stahuje s sebou i reálnou ekonomiku. Je nejvyšší čas nejen uvažovat o nových modelech, ale i o tom, co je nezbytné vykonat pro jejich uplatnění $v$ praxi. $\vee$ české ekonomice stále ještě existuje několik méně využívaných prvků, které však skrývají obrovský potenciál. Jedním z nejdůležitějších je družstevnictví, obsahující finanční spoluúčast členů - zaměstnanců. A právě k tomuto tématu se konal 14. října 2014 v budově Úřadu vlády seminář "Jak podpořit podnikání $v$ ČR pomocí finanční spolućčasti zaměstnanců? - inspirace jménem Mondragon", který měl v návaznosti na trendy EU zjistit možnosti a překážky pro rozvoj družstev $\vee$ ČR. Ve své zahajovací řeči na Semináři cestu k oživení družstevnictví nastínil Vladimír Špidla s poukazem na to, že je třeba „...zvýšit informovanost, odbourat mýty, inspirovat se dobrými př́klady a odstranit stávající překážky v právním systému."

Uplatnění modelu finanční spoluúčasti zaměstnanců má plnou podporu Evropské unie, která se touto problematikou dlouhodobě zabývá. Její výzkumy a expertízy zjistily mnoho překážek $v$ jednotlivých členských státech, ale jednoznačně poukazují na jeho smysluplnost a efektivitu. O finanční spoluúčasti zaměstnanců pojednávají tzv. PEPPER zprávy, které vypracovala Komise pro podporu účasti zaměstnanců na zisku a výsledcích podniku (I. 1991, II. 1997, III. 2006, IV. 2009).

Abychom zajistili ekonomickou, ekologickou i sociální udržitelnost, musíme si uvědomit, že nemáme mnoho času. Země se při pohledu z vesmíru jeví jako křehká, malá, omezená, zranitelná modrá kulička. Je tudíž paradoxní, že je devastována právě populací, která je na ní životně závislá. Kumulovaný zisk Ize využít i jinak než k upevnění moci a soukromého bohatství. Slova jako humanismus, etika, kooperace nemusí znít jako fráze. Existují reálné příklady, že filozofii podnikání mohou tvořit i jiné hodnoty než utilitarismus a pragmatismus. Jak řekl známý humanistický psycholog Erich Fromm (1900 - 1980): "Budoucnost lidstva závisí na našem srdci" a metaforicky tak již ve své době vyjádřil základní předpoklad pro naplnění udržitelného rozvoje.

\section{Životní úroveň ve vybraných regionech}

Zástupce Evropské komise Ramiro Cibrian na semináři nastínil možnosti porovnání životní úrovně konkrétních regiónů na základě hlavních indikátorů. Sorvnával Baskicko, coby region s velmi silnou průmyslovou tradicí, prosperující Bavorsko, Prahu a region Morava a Slezsko. Tyto čtyři regiony pak hodnotil v rámci jejich postavení v rámci 362 regionů podle OECD (Organizace pro hospodářskou spolupráci a rozvoj). Podrobné informace vyjdou $v$ připravovaném sborníku, vzpomeňme aspoň ty nejzajímavější. Baskicko $v$ mnoha parametrech vyniká mezi regiony ve Španělsku, zatímco u nás nejsou místní rozdíly tak markantní. Česká republika má vysokou úroveň vzdělanosti obyvatel (jsme v první čtyřce mezi 362 regiony). Téměř stejná úroveň vzdělanosti Prahy a Moravy však nezachraňuje schodek v míre nezaměstnanosti (Praha 3,3 \% - téměř jako Bavorsko, Morava a Slezsko až 9,6 \%). Oba naše regiony se nemohou chlubit svým životním 
prostředím a téměř na konci žebříčku se nacházíme $v$ př́ijmů našich obyvatel (27. ze 34 zemí). Oproti Baskicku (!) a Bavorsku vyděláváme o cca 7300 USD (Praha) až 12000 USD (cca 257000 Kč) na hlavu (Morava) méně.

\section{Př́padová studie: Mondragon}

S klíčovými podmínkami fungování hospodářského zázraku v baskickém Mondragonu seznámil účastníky Juan Manuel Sinde, bývalý ředitel a člen představenstva banky Caja Laboral. Mondragonská družstevní korporace (dále MCC) je největší ekonomickou skupinou v Baskicku. Tvoří ji 103 družstev, 122 výrobních závodů, 8 nadací, 1 podílová společnost, 10 podpůrných subjektů a 13 mezinárodních servisních společností. Se svými 74 tisíci zaměstnanci dosahuje tržeb 12,6 miliardy euro. Vlastnická práva má $40 \%$ zaměstnanců. Podmínkou k jejich získání byl vklad do společného kapitálu - členský poplatek ve výši 16 až 17 tisíc USD. Dnes sedmá největší společnost ve Španělsku vznikla v roce 1956, kdy katolický kněz José Maria Arizmendiarreta založil malou továrnu na topná tělesa. Výroba je $v$ současnosti soustředěna převážně na komponenty pro automobily a bílou techniku.

MCC přežilo mnohé těžké časy zejména díky morální nenapadnutelnosti kněžské autority a ryzího charakteru zakladatele, který spojil křestáanské učení se zdravým rozumem a nevídanou manažerskou strategií. MCC se vyhýbá krizovým situacím díky variabilitě ekonomických subjektů, které zastřešuje. Úspěch Mondragonu spočívá v motivačních faktorech zaměstnanců (seberealizační, radosti z práce, existenční, hmotné zainteresovanosti, morálního ocenění, ale i strachu), vysoké sociální úrovni péče o zaměstnance (včetně těch $v$ důchodu), akcionářské spoluvlastnictví, kolektivní způsob rozhodování a založení vlastní banky (pod názvem „zúčtovací středisko").

\section{„,Sociálně-etický kapitalismus" v praxi}

Čím se liší MCC od ostatních? Arizmendiarreta od začátku striktně dodržoval princip zaměstnaneckého spoluvlastnictví. V praxi to znamená demokratické rozhodování o všech významných činnostech družstva, princip solidarity při rozdělování zisku a ve mzdách (maximální rozdíl 1:6), dobré sociální zabezpečení, podpora dalšího vzdělávání zaměstnanců, penzijní fondy apod. Důraz je kladen na stabilitu zaměstnanosti. Člen družstva nemůže být propuštěn $v$ souvislosti $s$ ekonomickou výkonností podniku, ale je převeden do jiného. U zaměstnanců tak dosáhl značné osobní angažovanosti, pocitu zodpovědnosti a ztotožnění se s firmou - na rozdíl od dnes zažitých korporativních modelů, kdy se identity dosahuje prázdnými hesly, teambuildingem, nebo zastrašováním ztrátou práce. Výsledkem je mnohem vyšší produktivita práce, než u tradičně hierarchicky řizených firem. Podle Juana Manuela Sinde by jednotlivá družstva nikdy nedosáhla svého úspěchu bez angažovanosti zaměstnanců - spoluvlastníků, ale i správné korporátní strategie zaměřené na kvalitu, reinvestice zisku a péče o kulturní hodnoty.

Jedním ze základních pilírư Mondragonské družstevní korporace je vlastní banka Caja Laboral (založena v roce 1959), která představuje finanční zázemí korporace. Kromě správy kapitálových podílů zaměstnanců poskytuje též poradenskou a finanční pomoc jednotlivým družstvům, zejména pokud se ocitnou v krizové situaci. Bankovní a finanční služby realizuje prostřednictvím sítě kolem 370 poboček, její roční př́ijmy přesahují 330 milionů euro. Banka má více než 1800 zaměstnanců, volenou správu a řídí se stejnou k zákazníkům přivětivou - filozofí jako celá korporace. Jako první pomoc družstvům pro horší časy a přemostění krizových situací slouží solidární fondy, které spravuje pojištovna Lagun aro. Do solidárních fondů je pravidelně ukládána část korporátního zisku. Každoročně je do nich odváděno 10 až 30 procent. Krizová řešení bývají různá - od 
nasazení nového top managementu až po bankrot a následnou proměnu na novou družstevní jednotku. Cílem je nejen obnovení prosperity, ale hlavně udržení pracovních míst. Pokud je nutné novou jednotku "zeštíhlit", v rámci firemní solidarity se o ohrožené pracovníky postarají ostatní družstva. Peníze ze solidárních fondů slouží také k zakládání zejména dceřiných společností v zahraničí, např́klad v Latinské Americe. Od roku 1985 bylo založeno 257 nových podniků. Podíl ze zisku je ukládán rovněž do penzijních fondů zaměstnanců.

Neméně důležitou podmínkou úspěchu je podle Juana Manuela Sinde společné sdílení plánů a úkolů pro budoucnost. S tím souvisí vysoce transparentní a otevřená informační politika. Nejde jen o využívání podnikového intranetu, ale především o prolomení mnoha tabu - zaměstnanci např́ílad vědí jaký má kdo v družstvu plat, včetně nejvyšších manažerů. Zatímco u nás se ve firmách řeší pouze ekonomika, v Mondragonu dbají také na sdílení kulturních hodnot, vyznávají rovnost a důstojnost všech lidí, upřednostňují společné projekty před individuálními zájmy, plnění závazků vůči komunitě, týmovou práci apod. V roce 1997 se korporace zasloužila o otevření Baskické univerzity v Mondragonu, na kterou navazuje celý systém škol a výzkumných pracovištt. Dotace do vzdělávání a výzkumu spojují příjemné s užitečným. Kromě využívání nových trendů ve vědě a výzkumu souvisí také s daňovou politikou a představují smysluplný odečet $z$ daní.

Vedení firmy kolektivem vlastních zaměstnanců neprobíhá vždy úplně hladce, proto bylo postaveno školící centrum, kde jsou zaměstnanci pravidelně vzděláváni. Řídící pracovníci mají navíc $\mathrm{k}$ dispozici zkušené kouče. Korporace se netají svým zájmem o dobrou spolupráci s vládou a státními institucemi na všech úrovních. Cílem jejího systematického lobbingu je prosazování legislativních změn, které by zlepšily situaci družstevnictví. Velkým pomocníkem v lobbingu a propagátorem hodnot Mondragonské družstevní korporace je nezisková nevládní organizace Společnost přátel Arizmendiarrety. Samožrejmě, adaptované na moderní trendy a možnosti dnešní doby. Podporují např́iklad príbuzný americký systém ESOP (Employee stock ownership plan). V současnosti je připraven Návrh zákonu o novém modelu podnikání, jenž zohledňuje výše zmíněné prvky a který bude - po roční veřejné diskusi - předložen $v$ baskickém parlamentu do konce tohoto roku. A jak shrnout tajemství cesty k dosažení úspěchu do zkratky? "Žádné stižnosti, do akce!" - tak nadčasově pravil otec zakladatel, José Maria Arizmendiarreta (1915-1976).

\section{Družstevnictví znovu na scénu}

O aktuální situaci v družstevnictví v České republice referoval Rostislav Dvořák, předseda Svazu českých a moravských výrobních družstev (dále SČMVD). Podle jeho slov po pěti krizových letech nejlépe obstály (z hlediska výnosů a zaměstnanosti) malé a střední firmy, což je jedním z důkazů, že podpora družstevnictví má i u nás svoje opodstatnění.

Vznikem ekonomické organizace socialistických států (RVHP) v roce 1949 byla družstva vyňata z centrálního bilančního systému, tj. odsouzena k živoření, nebo úplnému zániku. Proto bylo dost překvapivé, když stát v 90 . letech jejich „kletbu" nezrušil, přesto, že podpora malých a středních domácích firem, coby základu ekonomiky státu, byla omílána téměř denně. Místo toho se náš trh bezprecedentně otevřel celému světu a zelenou dostalo zboží z importu. Dodnes u nás 80 \% středních firem pracuje jen na výrobě komponentů pro zahraničí - na rozdíl od našich sousedů v SRN. Podpora malých a středních firem chybí. Operativa převládá nad koncepcí. Proč se ještě stále nemůžeme rovnat silným ekonomikám - my, kteří jsme byli za Masarykovy republiky mezi prvními třemi na světě? Proč se nesnažíme dostat na mezinárodní trhy i naše malé a střední firmy? 
Vláda premiéra Sobotky přináší naději - je první, která se zaobírá hospodářskou koncepcí, která by měla ekonomický vývoj v ČR výrazně vylepšit. SČMVD ve spolupráci s Družstevní asociací ČR vypracoval Projekt restrukturalizace hospodářství ČR k posílení stabilizace ekonomiky a zaměstnanosti prostřednictvím družstevních výrobních podniků a malých a středních firem. Tento projekt je plně v souladu s přijatým usnesením Evropského parlamentu č. 2012/2321 (IMI) o přispění výrobních podniků družstev a malých a středních podniků k překonání krize, které nabízí řadu východisek. Stanovuje si šest hlavních priorit: legislativní změny; podpora podnikání; exportu; vzdělávání (strukturální změny středních - zejména učňovských - škol), vědu, výzkum, inovace; podpora zaměstnanosti (možnost přeměny firem na družstva - $v$ rámci restrukturalizace firem $v$ insolvenčním řizení je to jedna $z$ vhodných forem převzetí firmy zaměstnanci) a podpora integračního sociálního podnikání družstevní formou (zaměstnávání občanů se zdravotním postižením).

SČMVD sdružuje přes 200 družstev. Od menších, s obratem výroby v řádu jednotek miliónů až po družstva dosahující miliardy. Mnohé z nich zaměstnávají více než $50 \%$ pracovníků se zdravotním postižením. Stávají se tak významnou součásti sociálního systému společnosti. "Holt, majetek na rozprodávání tady již není, jsme tady my - tvưrci hodnot", uzavřel svoji řeč Rostislav Dvořák.

S podporou EU a rozumných kompetentních lidí na klíčových místech budeme hodnoty vytvářet i nadále, ale věřme, že již beze strachu a depresí z materiální nejistoty. Přesto, že česká podnikatelská filozofie mnohdy postrádá duchovní rozměr Mondragonu, jako by ekonomické myšlení nevyžadovalo určitou morální úroveň, zdá se, že se blýská na lepší časy; že náš porevoluční dřevní kapitalismus se svou nepoctivostí, obelháváním a okrádáním druhých definitivně zmizí na smetišti dějin a veškerý život společnosti prostoupí již téměř pohaslé etické hodnoty, včetně společenské odpovědnosti každého z nás. Cesta k udržitelnosti, jež byla tématem tohoto semináře, je realizovatelná - a o to víc lákavá.

\section{Literatura}

- The 'PEPPER' reports. Eurofound. [citováno 23. 11. 2014 ]. On-line získáno: http://www.eurofound.europa.eu/areas/participationatwork/pepperreports.htm

- Mondragon-corporation. [citováno 23. 11. 2014 ]. On-line získáno: http://www.mondragon-corporation.com/

- Strange, S. (1986). Casino capitalism. Oxford, UK: B. Blackwell. 


\section{Obrázek č. 1}

Mimořádně inspirativní seminář Rady vlády pro udržitelný rozvoj moderovala ředitelka Odboru pro udržitelný rozvoj Anna Kárníková. Se sluchátky na uších vedle ní sedí baskičtí experti Juan Manuel Sinde a Ramiro Cibrian. Slovo má předseda Svazu českých a moravských výrobních družstev, Rostislav Dvořák.

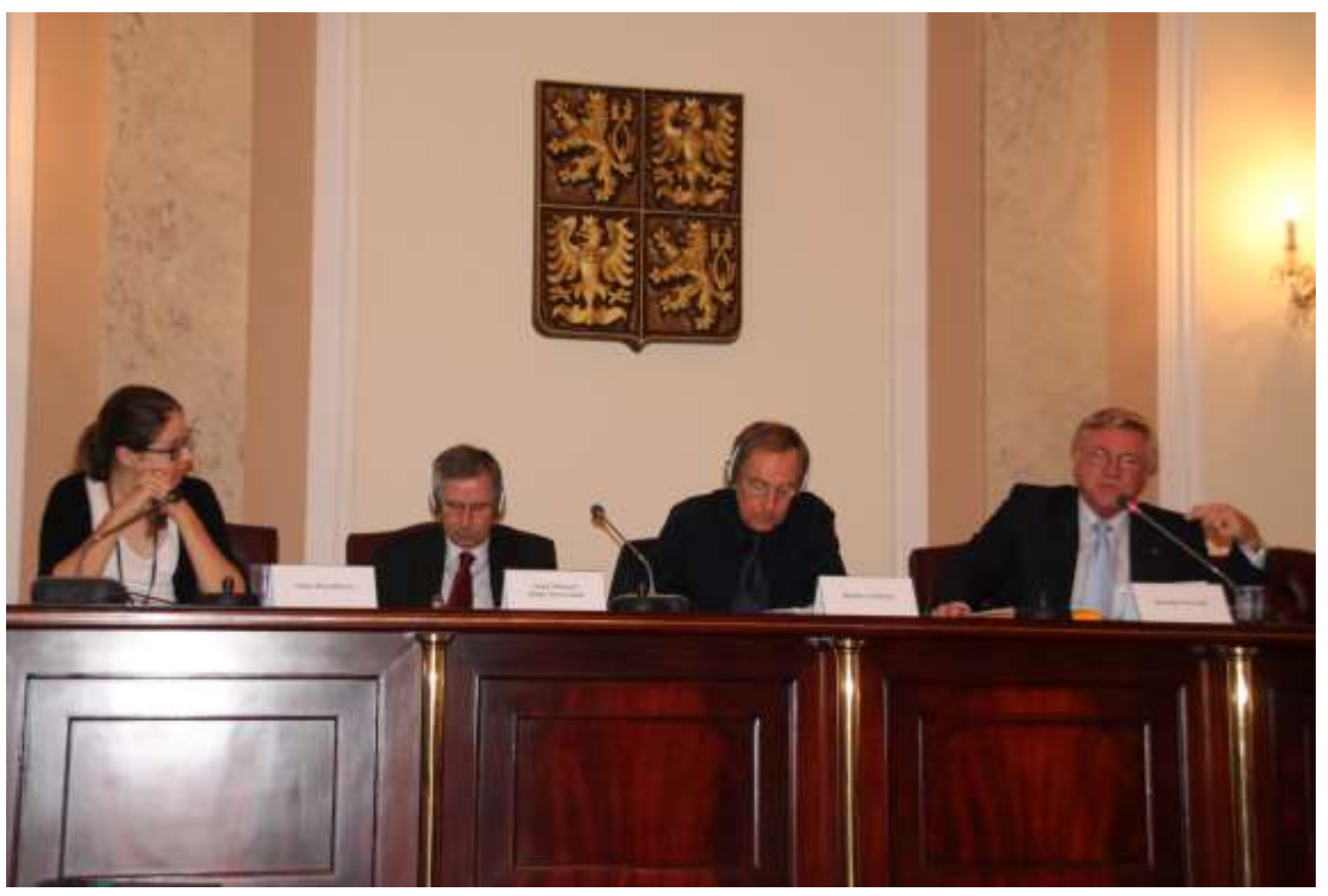

\section{PhDr. Beata Binková}

Zabývá se environmentální problematikou a propagací společenské odpovědnosti a udržitelného rozvoje $v$ médiích. Je součástí PR týmu Rady vlády pro udržitelný rozvoj na Úřadu vlády ČR. S cílem popularizovat a šírit informace o udržitelném rozvoji mezi širokou veřejností založila neziskový dobrovolnický spolek EkoFutura s nezávislým envi-magazínem téhož názvu. 